\title{
Obraz emocjonalności w tekstach folkloru
}

\section{Agnieszka Wełpa, Językowe komunikowanie uczuć w pieśniach ludowych z Warmii i Mazur, LIBRON, Kraków 2014, 440 s.}

Od powstania teorii ekspresywności Stanisława Grabiasa - jak dotąd jedynej w Polsce tak wieloaspektowej propozycji oglądu zjawisk językowych związanych z wyrażaniem osobowości nadawcy - minęło już ponad trzydzieści lat. Nadal jednak jest zauważalny deficyt publikacji z tego zakresu. Brakuje zwłaszcza większych opracowań poświęconych sposobom uzewnętrzniania uczuć w zróżnicowanych genologicznie tekstach. Tę lukę wypełnia rozprawa Agnieszki Wełpy.

Książka składa się z trzech części: Założenia wstępne, Prezentacja $i$ analiza materiatu, Podsumowanie (s. 9-393) poprzedzonych krótkim Wprowadzeniem (s. 7-8), a obudowę opracowania tworzą: Wykaz wsi (s. 395-398), Źródta (s. 399), Literatura (s. 401-437) oraz streszczenie w języku angielskim (s. 439-440).

Cel, który sobie autorka postawiła, dotyczy analizy warstwy językowej pieśni ludowych z Warmii i Mazur. „Obszar badań obejmuje sposoby komunikowania doświadczeń emocjonalnych w pieśniach śpiewanych i przekazywanych z pokolenia na pokolenie przez ludność terenów polskojęzycznych, ale pozostających przez wieki poza granicami Polski” (s. 7). $\mathrm{Z}$ obranego korpusu tekstowego badaczka wyekscerpowała konstrukcje składniowe oraz frazeologizmy informujące o emocjach doznawanych przez bohaterów pieśni.

Przeprowadzone analizy bogatego zbioru elementów językowych zostały poprzedzone prezentacją Założeń wstępnych (s. 9-34). Składa się na tę część dziewięć rozdziałów. Pierwszy, zatytułowany Krótki zarys historii Warmii i Mazur (s. 9-10), wypełniają podane w syntetycznej i przejrzystej formie uwagi na temat dziejów obszaru, pozwalające zrozumieć zróżnicowanie na płaszczyźnie językowej. Warmia i Mazury zamieszkiwane były 
przez różne plemiona, między innymi przez Prusów, Sasinów, Galindów, Jaćwięgów. Państwo polskie sąsiadowało bezpośrednio z plemionami pruskimi, z którymi dochodziło do konfliktów. Sposobem na ich zażegnanie miało być sprowadzenie przez Konrada Mazowieckiego w 1226 roku rycerzy zakonu krzyżackiego. W efekcie plemiona pruskie zostały pokonane i schrystianizowane, a na tamtejsze ziemie zaczęli przybywać osadnicy z Niemiec, następnie Polacy i Prusowie (w ramach kolonizacji wewnętrznej). Na części terenów wschodnich Mazur pojawili się także Litwini. Walki między zakonem krzyżackim a sprzymierzonymi wojskami polskimi, pruskimi i litewskimi w XIV i XV wieku doprowadziły do podziału Prus na Prusy Królewskie (obejmujące Pomorze Gdańskie, ziemię chełmińską, okolice Malborka i Elbląga oraz Warmię tzw. biskupią) i Prusy Książęce (pozostałe tereny będące lennem polskim). Od tego momentu dzieje Warmii i Mazur potoczyły się odmiennie.

Rozdział drugi Gwary Ostródzkiego, Warmii i Mazur (s. 11-14) przynosi inwentaryzację cech gwarowych (stan sprzed II wojny światowej) trzech regionów: Warmii, Mazur oraz różniącego się pod względem językowym od sąsiednich krain Ostródzkiego, traktowanego niekiedy jako część Mazur. Z takim ujęciem spotykamy się między innymi w omawianych zbiorach pieśni, w których nie wydziela się osobno rejonu Ostródzkiego. W tej części pracy autorka skupia się na najważniejszych cechach fonetycznych (fonetyka międzywyrazowa, obecność mazurzenia lub jego brak, systemy wokaliczny i konsonantyczny) oraz fleksyjnych różniących omawiane gwary, a następnie przechodzi do wyliczenia wspólnych (także leksykalnych) właściwości.

Następny, dość skromny rozdział jest poświęcony lingwistycznym analizom związanym z uczuciami (Językoznawstwo: badania dotyczace uczuć, s. 15-17). Agnieszka Wełpa wymienia tutaj dwa procesy ekspresji: komunikowanie emocji (badaczka uznaje terminy uczucie i emocja - jak większość lingwistów - za synonimy) oraz ich wyrażanie. „Komunikowanie uczuć” to inaczej mówienie o nich, natomiast „wyrażanie” łączy autorka z ekspresywnością językową. W swoich rozważaniach odwołuje się do propozycji Anny Wierzbickiej, która postulowała definiowanie emocji za pomocą indefinibiliów, oraz do ustaleń Iwony Nowakowskiej-Kempnej zarówno tych wcześniejszych, które powstały w nurcie badań strukturalistycznych, jak i późniejszych, wykorzystujących narzędzia badawcze 
wypracowane na gruncie kognitywizmu. Rozdział wieńczy krótki rejestr nowszych prac z zakresu językoznawczego opisu uczuć.

W omawianej książce nie zabrakło też przeglądu najważniejszych (choć nie wszystkich) problemów związanych z psychologicznymi aspektami emocji (Psychologia: badania dotyczace uczuć, s. 17-20). W centrum zainteresowania autorki znalazły się takie zagadnienia, jak: ewolucja mózgu i jego elementów zaangażowanych w rozwój emocji, ośrodki odpowiedzialne za procesy emocjonalne, neurotransmitery, biologiczne cechy procesów emocjonalnych, nadto relacje między emocjami a procesami intelektualnymi, problem emocji podstawowych, związki lewej i prawej półkuli mózgu z emocjami, typologia emocji uwzględniająca ich walencję (emocje pozytywne i negatywne) oraz eksplikacje terminów emocja (doznanie właściwe ludziom i zwierzętom) i uczucie (doznanie charakteryzujące prawdopodobnie wyłącznie człowieka).

Dwa następne rozdziały Pieśni ludowe (s. 20-25) oraz Pieśni ludowe na Warmii i Mazurach (s. 25-28) przynoszą zwięzłą historię naukowych zainteresowań pieśniami ludowymi, opis ich statusu gatunkowego (wędrowny charakter, powtarzalność stałych motywów fabularnych, pierwotna oralność, szczególna rola wykonawcy, wariantywność tekstów, typizacja bohaterów i akcji, uproszczona psychologia postaci, linearność i dynamizm w prezentacji zdarzeń, formuliczność pieśni, kontaminacje tekstów, poetyzmy, zdrobnienia), a także niezwykle interesujący poznawczo - sporządzony w porządku chronologicznym - wykaz najważniejszych zbiorów warmińsko-mazurskich pieśni ludowych (rękopiśmiennych i wydanych drukiem). Uwagę czytelnika przykuwają nie tylko tytuły kolejnych zbiorów, ale także nazwiska osób działających na rzecz utrwalenia folklorystyki pieśniowej. Znalazły się wśród nich takie postaci, jak: Michał Tomasik z Królewca, Jan Nieszczery z Rynu, Jan Dzubiel z Wysokich koło Ełku, Gustaw Gerss z Mikołajek, Gustaw Gizewiusz, Wojciech Kętrzyński, Karol Sieniawski, Augustyn Steffen, Oskar Kolberg i wielu innych.

$\mathrm{Na}$ kolejnych stronach książki Agnieszka Wełpa zarysowuje metodologiczne zaplecze prowadzonych w rozprawie analiz. Opiera je na koncepcji pola znaczeniowego (wyrazowego), którą klarowanie wyjaśnia w rozdziale Metodologia (s. 28-30). Przywołuje w tym miejscu prekursorskie propozycje Wilhelma von Humboldta, Ferdinanda de Saussure'a oraz klasyczne już ujęcia Josta Triera i Waltera Porziga. Odnotowuje poza tym 
polskie opracowania przybliżające teorię polową oraz wykorzystujące tę metodologię do opisu słownictwa denotującego uczucia.

Kolejne uwagi autorka zawarła w rozdziale Charakterystyka materiału i źródeł (s. 30-32). Znajdujemy tutaj informacje dotyczące obszernej bazy materiałowej. Tworzą ją pieśni ludowe gromadzone na Warmii i Mazurach od pierwszej połowy XIX wieku do końca lat 70. XX stulecia i zebrane w następujących publikacjach: Obyczaje weselne pomieszczone w opracowaniu historyczno-kulturowym Karola Sieniawskiego Biskupstwo warmińskie (1878), Hermann Frischbier Dziesięć pieśni mazurskich z czasopisma Altpreussiche Monatsschrift (1887-1888), Augustyn Steffen Zbiór polskich pieśni ludowych z Warmii (t. 1 - 1931, t. 2 - 1934, t. 3 1937), Pieśni ludowe Mazur $i$ Warmii zestawione przez Władysława Gębika (1952), Pieśni ludowe Warmii i Mazur wybrane i opracowane przez Mariana Sobieskiego (1955), Oskar Kolberg Mazury Pruskie (1966), Śpiewa wiatr od jeziora. Pieśni ludowe Warmii i Mazur - zebrane i opracowane przez Marynę Okęcką-Bromkową (1966), Wojciech Kętrzyński Pieśni gminne ludu mazurskiego w Prusach Wschodnich (1968) oraz pięciotomowy zbiór Barbary Krzyżaniak i Aleksandra Pawlaka Warmia i Mazury (2002) obejmujący pieśni doroczne i weselne, balladowe i społeczne, zalotne i miłosne, rodzinne i taneczne, religijne i popularne. Pierwszą część publikacji wieńczą refleksje na temat struktury jej rozdziałów oraz sposobu prezentacji materiału (s. 33-34).

Drugi, najobszerniejszy dział rozprawy (s. 35-385) ma charakter materiałowo-interpretacyjny. Analizie poddano wyekscerpowane z badanych pieśni ludowych Warmii i Mazur konstrukcje syntaktyczne informujące o doświadczanych przez bohaterów uczuciach oraz frazeologizmy somatyczne, które wiążą się z emocjami. Autorka objęła obserwacją uczucia pozytywne i negatywne, wśród których znalazły się: miłość, sympatia, radość, nadzieja, współczucie, tęsknota, smutek, rozpacz, zazdrość, pogarda, gniew, strach, wstyd, nienawiść. Każdy z czternastu rozdziałów poświęconych wymienionym emocjom ma podobną, przejrzystą budowę. Rozpoczyna się od ustaleń psychologów (ewentualnie filozofów i przedstawicieli innych nauk społecznych) oraz językoznawców na temat analizowanego uczucia. Uwagi lingwistyczne dotyczą etymologii wyrazów (głównie rzeczowników i czasowników) oraz definicji leksykograficznych zaczerpniętych zarówno ze słowników ogólnych (pod redakcją Witolda 
Doroszewskiego oraz Mirosława Bańki), jak i ze Słownika gwar Ostródzkiego, Warmii i Mazur.

Zgromadzony materiał uporządkowano według pól leksykalnych. W ich obrębie wydzielono mikropola będące nazwami rzeczownikowymi (np. „miłość”, „kochanie”, „radość”, „radowanie”, „pociecha”, „wesele”, „litość”, „tęsknica”, „smutek”, „smętek”, „zazdrość”, „wzgarda”, „,złość”, „gniew”, „trwoga”, „bojaźń”, „lękanie”, „wstyd”, „sromota”), czasownikowymi (np. „miłować”, „umiłować”, „wielbić”, „lubić”, „najrzeć”, „radować [się]”, „weselić się”, „tęsknić”, „frasować się”, ,zawstydzić się”, „nienawidzić”), przymiotnikowymi (np. „radosny”, „rad”, „żałosny”, „niemiłosierny”, „sfrasowany”, ,zatroskany”, „wściekły”) lub przysłówkowymi (np. „wesoło”, „litośnie”, „kuczno”, „smutno”, „smutnie”, „smętnie"). Na ostatnie mikropole składają się frazeologizmy somatyczne (np. z komponentami „serce”, „oko”, „ręka”, „,noga” itp.), określenia zachowań mimicznych i gestycznych (często sfrazeologizowane). Kolejność prezentacji konstrukcji językowych jest podyktowana częstością występowania poszczególnych leksemów w badanych pieśniach. Interpretacje wszystkich zaobserwowanych zjawisk Agnieszka Wełpa ilustruje odpowiednimi wyimkami z pieśni (wraz z lokalizacją geograficzną i źródłową). Przywołuje ponadto warianty pieśni, w których zanotowano identyczny schemat składniowy.

Ostatnia część rozprawy to Podsumowanie (s. 387-393) obejmujące dwa rozdziały: Konstrukcje składniowe stuzace komunikowaniu uczuć w pieśniach ludowych (s. 387-392) oraz Zakończenie (s. 392-393). W pierwszym z nich autorka zestawia najbardziej produktywne oraz rzadziej wykorzystywane schematy syntaktyczne, w których pojawiają się nazwy emocji. Jest ich siedemnaście (np. ktoś + forma osobowa czasownika „mieć” + rzeczownikowa nazwa uczucia, ktoś + forma osobowa czasownika „robić” + „w” + nazwa uczucia w miejscowniku, ktoś + forma osobowa czasownika „robić” + „z”/,od” + nazwa uczucia w dopełniaczu, ktoś/coś + czasownik nazywający uczucie w formie osobowej + kogoś, ktoś + czasownik nazywający uczucie w formie osobowej + ,za” coś, komuś + forma osobowa czasownika „być” + przysłówek nazywający uczucie). Drugi rozdział wypełniają wnioski wysnute na podstawie przeprowadzonych badań.

Lektura książki Agnieszki Wełpy nasuwa kilka uwag. Zastanawia przede wszystkim tytuł monografii. Jego komponentem jest termin 
komunikowanie, który - zgodnie z propozycją Stanisława Grabiasa (wyłożoną w publikacji O ekspresywności języka. Ekspresja a słowotwórstwo, Lublin 1981) - odnosi się do jednego z trzech typów ekspresji (rozumianej szeroko jako proces eksplicytnego bądź implicytnego ujawniana się osobowości mówiącego w wypowiedzi). Komunikowanie uczuć (in. relacjonowanie, opisywanie, referowanie, nazywanie emocji, mówienie o emocjach, sąd o emocjach) to ich ujawnianie za pomocą wypowiedzeń w modusie „wiedz, że...”, czyli informowanie o uczuciach pod asercją. Proces ten opiera się na jednostkach leksykalno-frazeologicznych wprost (eksplicytnie) określających emocje. Tak pojmowane komunikowanie ma charakter językowy (niejęzykowo, ściślej rzecz ujmując: parawerbalnie i niewerbalnie, można uczucia przejawiać). Zbędne jest zatem zastosowanie przymiotnika ,językowe" w tytule opracowania.

Z komunikowaniem emocji wiąże się także przemilczany przez autorkę problem miejsca frazeologizmów odnoszących się do uczuć (typu: „X stanął jak wryty”, „x ma duszę na ramieniu”, „serce się kraje”) w obrębie trzech typów ekspresji. Na ogół zalicza się je - i tak też czyni Agnieszka Wełpa - do środków językowych komunikujących emocje. Są jednak badacze (np. Iwona Nowakowska-Kempna), którzy postrzegają tego typu jednostki nieciągłe jako wyrażające uczucia (między innymi ze względu na ich zabarwienie emfatyczno-emocjonalne).

W krótkim rozdziale poświęconym lingwistycznym badaniom nad emocjami brakuje szczegółowego omówienia wskazanej koncepcji S. Grabiasa (nieco później uzupełnionej przez Agnieszkę Mikołajczuk w artykule $O$ wyrażaniu i komunikowaniu uczuć w języku polskim (na przykładzie radości), w: Wyrażanie emocji, red. K. Michalewski, Łódź 2006, s. 84-93). Autorka sięga po terminy „wyrażanie” (uczuć), ,ekspresywność języka”, ale ich nie eksplikuje. Wyrażanie emocji można rozumieć dwojako: jako wszelkie możliwe sposoby uzewnętrzniania uczuć lub jako jeden z trzech typów ekspresji (poza wspomnianymi wcześniej przejawianiem i komunikowaniem). Ekspresywność językową łączy się z właściwościami (składnikami) znaków werbalnych wskazującymi albo na ich cechy stylistyczne (ujęcie szersze), albo wyłącznie na uczuciowy stosunek nadawcy do rzeczywistości pozajęzykowej (ujęcie węższe). Takich rozróżnień Agnieszka Wełpa nie przeprowadza.

W obrębie językoznawczych opisów emocji badaczka sytuuje tylko opracowania ,analizujące sposoby komunikowania uczuć, mówienia 
o nich oraz prace analizujące językowe sposoby wyrażania uczuć (np. z wykorzystaniem ekspresywności języka)" (s. 15). Nie dostrzega publikacji podejmujących problem przejawiania emocji (warto w tym miejscu przywołać choćby artykuł Karoliny Sykulskiej Język emocji - foniczne środki ekspresywne, „Poradnik Językowy” 2003, z. 5, s. 6-20 czy takie na przykład opracowania, jak: Katarzyny Klessy, Agnieszki Wagner, Magdaleny Oleśkowicz-Popiel Using „Paralingua” database for investigation of affective states and paralinguistic features, „Speech and Language Technology" 2011/2012, vol. 14/15, s. 71-91, Agnieszki Wagner Emotional speech production and perception in Polish: A framework of analysis, „Speech and Language Technology” 2011/2012, vol. 14/15, s. 163-183).

Zastanawia czytelnika, dlaczego rozdział Psychologia: badania dotyczace uczuć nie poprzedza części poświęconej lingwistycznym aspektom emocji. Wszak niektóre podstawowe ustalenia językoznawców dotyczące uczuć, na przykład ich podział na uczucia pozytywne i negatywne czy na afekty i postawy (stany) emocjonalne, mają swoje źródło właśnie w psychologicznej charakterystyce tych zjawisk. Szkoda, że wśród poruszanych przez badaczkę zagadnień nie znalazły się składniki emocji, które wiążą się ze zmianami w organizmie człowieka (np. wyższe ciśnienie krwi, słabsze tempo akcji serca, wyższa temperatura obwodu ciała, szybki oddech) obejmujące narządy wewnętrzne (takie jak np. serce, żołądek, jelita, mięśnie), ruchy ciała (np. opuszczenie ramion lub głowy, skurczenie się ciała, znieruchomienie, tzw. odruch skroniowo-barkowy) czy wyrazy twarzy (np. uśmiech, uniesione brwi, otwarcie ust). Zmiany biologiczne znajdują bowiem odzwierciedlenie w materiale językowym, także tym analizowanym przez Agnieszkę Wełpę (chodzi tu między innymi o frazeologię somatyczną ujmującą objawy uczuć).

Autorka rezygnuje także z przybliżenia czytelnikowi różnych kryteriów podziału emocji. Ogranicza się do zasygnalizowania najważniejszej z punktu widzenia swojej pracy typologii opierającej się na walencji uczuć, czyli na ich znaku dodatnim bądź ujemnym. Wspomina także o taksonomiach wyodrębniających uczucia podstawowe (pierwotne) i złożone (wtórne) oraz emocje związane z popędami, które występują u ludzi i zwierząt, i uczucia wyższe (intelektualizowane), właściwe - jak się przypuszcza - wyłącznie człowiekowi. Z punktu widzenia semantyki nazw emocji ważna wydaje się również - nieobjaśniona przez badaczkę w Założeniach 
wstępnych - stratyfikacja uczuć uwzględniająca ich natężenie oraz trwanie, czasem w opisie zgromadzonego materiału przez Agnieszkę Wełpę wykorzystywana, o czym świadczą występujące na kartach książki terminy „stan emocjonalny” (odnoszący się do uczuć długotrwałych, np. ss. 24, 72, 79, 82) czy „nastrój” (np. s. 206).

Pytanie o metodologiczne zaplecze dokonywanych w rozprawie obserwacji rodzi się podczas lektury jej części analitycznej. Padają w niej określenia typu „konceptualizacja”, „schemat wyobrażeniowy”, „profilowanie”, „struktura predykatowo-argumentowa”, będące terminologicznymi sygnalizatorami innych jeszcze - niż teoria polowa - metodologii opisu.

Zastanawiają niektóre decyzje Agnieszki Wełpy związane z uznaniem na przykład takich jednostek językowych, jak ,śmiać się”, „podśmiać się”, „roześmiać się” (s. 137) za frazeologizmy somatyczne. Pewien niedosyt budzi też nieodnotowywanie przez autorkę takich - widocznych w przywoływanych fragmentach pieśni - zjawisk emocjonalnych, jak gradacja, ambiwalencja i gama uczuć.

Nie ulega jednak wątpliwości, że książka Agnieszki Wełpy jest pionierskim opracowaniem sposobów komunikowania uczuć w polskich pieśniach ludowych. To atrakcyjne poznawczo zagadnienie nie było do tej pory przedmiotem tak wnikliwych obserwacji. Wybór obiektu analiz zasługuje na uznanie, a dzięki odpowiednio dobranemu instrumentarium badawczemu Agnieszka Wełpa osiągnęła zamierzony cel.

Imponująco przedstawia się bogaty korpus tekstowy poddany drobiazgowemu opisowi. Wszystkie propozycje interpretacyjne autorki są rzetelnie udokumentowane licznymi cytatami z branych pod uwagę pieśni. $\mathrm{Na}$ podkreślenie zasługuje ponadto dogłębna lektura tych tekstów, dostrzeganie roli kontekstu w przyporządkowywaniu odnotowanych nazw uczuć do odpowiedniego pola leksykalnego. Niektóre nazwy emocji bowiem mają charakter polifunkcyjny, o ich wartości semantycznej przesądzają uwarunkowania kontekstowe i sytuacja. Tak na przykład wyraz „rad” występuje w niektórych pieśniach nie tylko jako wykładnik radości oraz sympatii, ale także miłości (s. 88), leksem, ,żal” z kolei może komunikować zarówno smutek, jak i współczucie (s. 149).

Odnotować również należy obszerną literaturę przedmiotu. Obejmuje ona nie tylko publikacje wykorzystywane w recenzowanej monografii, ale 
także te nieprzywoływane przez badaczkę w toku wywodu (a dotyczące różnych typów ekspresji językowej). Tak sporządzona lista ma stanowić - to słuszny zamysł - podpowiedzi lekturowe dla zainteresowanych tematem; jest to jednak ryzykowne rozwiązanie, naraża bowiem autorkę na zarzut pominięcia niektórych opracowań (zwraca na przykład uwagę nieobecność w wykazie niezwykle ważnej rozprawy Artura Rejtera Leksyka ekspresywna w historii języka polskiego. Kulturowo-komunikacyjne konteksty potoczności, Katowice 2006 czy studium Pawła Nowakowskiego Emocjonalne podłoże wypowiedzi językowych. Zarys problematyki z perspektywy biolingwistyki, „Język. Komunikacja. Informacja” 2006, t. 1, s. 143-155).

O wartości opracowania Agnieszki Wełpy świadczą także interesujące wyniki naukowe. Autorka przekonująco dowiodła, że emocje to najważniejszy temat pieśni ludowych. Ukazała ponadto w analizowanych tekstach żywotność przestarzałych (nieznanych polszczyźnie ogólnej) schematów składniowych oraz form archaicznych w zakresie słownictwa nazywającego uczucia (,frasunek”, „,sromota”, „miłować”, „,bojać się”, „smęcić się”). Te ostatnie składają się na zbiór swoistych poetyzmów ludowego stylu artystycznego. $\mathrm{Z}$ analizowanego materiału wyłania się też ludowa wizja świata, w której mieszczą się wyobrażenia o typach bohaterów: kobiety są bardziej emocjonalne od mężczyzn; tęsknota, nadzieja i zazdrość to uczucia niemal wyłącznie przypisywane kobietom (takie emocje przeżywają czasem osoby starsze lub słabsze z jakiegoś powodu); młode osoby (zarówno kobiety, jak i mężczyźni) często przeżywają miłość, starsze natomiast doświadczają raczej smutku i płaczu; istoty boskie odczuwają na ogół współczucie/miłosierdzie, choć i inne emocje nie są im obce. Ostatni wniosek: w licznych pieśniach ludowych uczucia manifestowane są również za pomocą jednostek językowych odsyłających do zachowań parawerbalnych i niewerbalnych.

Jestem przekonany, że książka Agnieszki Wełpy znajdzie odbiorców wśród szerokiego grona czytelników. Zainteresuje z pewnością nie tylko językoznawców dialektologów i lingwistów zajmujących się ekspresją językową, ale także na przykład etnografów czy antropologów kulturowych. 